Check for updates

Portsmouth, UK

Cite this as: BMJ 2021;373:n1023 http://dx.doi.org/10.1136/bmj.n1023 Published: 20 April 2021

\section{Covid-19: Spike in cases in Chile is blamed on people mixing after first vaccine shot}

Luke Taylor

Cases of the novel coronavirus are surging in Chile despite the country having one of the most successful vaccine rollouts in the world.

Chile reported 7370 infections on 18 April, down slightly on the record high of 9151 cases reported on 9 April. Some $96 \%$ of the intensive care beds in the country are occupied as hospitals come under growing strain from the most severe coronavirus

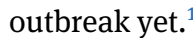

The surge in cases comes despite a speedy vaccine rollout, a nationwide nightly curfew, and restrictions on movement imposed across most of the country. The case numbers have provoked concern and speculation around the world as to why the transmission rate remains high despite $40 \%$ of Chileans ${ }^{2}$ having received at least one vaccine dose-the third highest rate in the world after the UK and Israel.

"The country may have been too optimistic after their vaccine rollout and opened up too quickly, especially to internal travel during the summer holiday season," said Michael Touchton, from the University of Miami's Observatory for the Containment of Covid-19 in the Americas. Chile reopened its borders in November 2020 when infections had dropped from its June peak to around 1400 cases a day. It also permitted domestic travel during the country's December to February holiday season this year, when restaurants, shops, and holiday resorts reopened.

Careless behaviour during the vacations likely facilitated the virus's spread, experts said.

"At the beginning of the vaccine campaign there was a message from government that 'vaccines are on their way so the pandemic will end soon.' Everyone stopped taking care, stopped wearing masks, and joined big crowds during the holiday season," said Claudia Cortés, an infectious diseases specialist at the University of Chile.

Most vaccinated Chileans have only had a single dose, meaning they are still largely unprotected from infection. A study published by researchers at the University of Chile on 6 April, in which Cortés was not involved, found that the CoronaVac vaccine was $56.5 \%$ effective in preventing infections two weeks after a second dose but only $3 \%$ effective after a single dose. ${ }^{3}$ Ennio Vivaldi, the university's rector, concluded that until two weeks after the second dose is administered the vaccine "has no significant effect." He added, "We have to be empathetic, take care of ourselves, wear masks, follow health measures, and stay home even if we have the vaccine. That's the only way we're going to get out of the pandemic."
Some $93 \%$ of the doses administered were the CoronaVac vaccine, manufactured by Chinese state run pharmaceutical Sinovac, and $7 \%$ the more effective Pfizer BioNTech vaccine. Chile's CoronaVac study results are comparable to previous CoronaVac trials elsewhere and "were not a surprise," said Cortés. "The error was that the government was not clear enough in explaining the importance of the second dose," she said. "We need to be very clear in our risk communication. You need to wait until the second dose.”

Infections in Chile are also likely being driven by the more transmissible P.1 variant first identified in Brazil, which is believed to be playing a role in a current surge in cases across South America. New coronavirus infections are increasing in Argentina, Brazil, Bolivia, Colombia, Paraguay, Peru, Uruguay, and Venezuela, said the Pan-American Health Organization (PAHO) in a briefing on 14 April. ${ }^{4}$

PAHO's director, Carissa Etienne, called on governments to focus on public health measures to bring the crisis under control and not to rely on vaccines. "I cannot stress this enough: for most countries, vaccines are not going to stop this wave of the pandemic," she said.

Covid Chile. ¿Cuáles son las dimensiones disponibles? [Spanish]. 2021. www.icovidchile.cl/capacidad-hospitalaria.

2 Our World in Data. Statistics and research: coronavirus (covid-19) vaccinations. https://ourworldindata.org/covid-vaccinations.

3 Tapia M. Después de 14 días de la segunda dosis: acunas contra el SARS-CoV2 muestran 56.5 por ciento de efectividad en la prevención de contagios. [Spanish]. 6 April 2021. www.uchile.cl/noticias/174186/resultados-primer-estudio-de-efectividad-de-las-vacunas-en-chile.

PAHO. PAHO director warns that vaccines alone will not stop current covid-19 surge. 14 April 2021. www.paho.org/en/news/14-4-2021-pahodirector-warns-vaccines-alone-will-not-stop-current-covid-19-surge.

This article is made freely available for use in accordance with BMJ's website terms and conditions for the duration of the covid-19 pandemic or until otherwise determined by BMJ. You may use, download and print the article for any lawful, non-commercial purpose (including text and data mining) provided that all copyright notices and trade marks are retained. 